\title{
Atypical Endocervical Cell
}

National Cancer Institute

\section{Source}

National Cancer Institute. Atypical Endocervical Cell. NCI Thesaurus. Code C141518.

An abnormal endocervical cell found in a cervical smear. It may be related to an

inflammatory or neoplastic process. 